\title{
Survey and Study on the Physical Quality of Students of Qingdao University of Science and Technology
}

\author{
Yuping Chen \\ Qingdao University of Science \& Technology \\ 099 mailbox, 43 Zhengzhou Road, Qingdao 266042, China \\ E-mail: chenyuping222@163.com
}

\begin{abstract}
Some methods such as application of examination, statistic analysis, questionnaire survey, induction and conclusion, theoretical study and so on, were used to study the problems existing in the development situation of physical quality condition of our university's students and their causes. Some feasible suggestions were also proposed about how to improve their physical quality.
\end{abstract}

Keywords: College student, Physical quality, Survey, Examination, Guideline

\section{Question statement}

At the university stage, students' physical quality should be enhanced or maintain unceasingly at the high level. However, for many years in the physique investigation and statistics among the new student while they come to the college at the first time, and the Physical exercise compliance test process once per- year, we find that, physical quality of the higher grades students has the declining trend. In order to reverse this tendency, and have a scientific guidance to the college students' physical excises, and foster the college students to have the habits of to take exercises, we university physical educator need to study the changing of the students' physical quality earnestly, try to understand the university students' state of motion and the physical training behavior. Regular physical fitness testing of students assessed, which will help identify problems and is helpful in the school to let morality, intelligence and physique developed together. In order to make the students strengthen their physique at school period effectively. Guaranteed students has the highly effective work's physical ability which the vigorous and healthy body and spirit and the occupation need to lay the foundation after school period and even graduated.

\section{Object of study and research technique}

\subsection{Object of study}

There are 733 students at the 2006 level of undergraduates joined this investigation, 736 on the 2005 level, 250 on the 2004 level, 250 on the 2003 level. 1209 of them are guys, 760 of them are girls, and there are 1969 in all. Most of them are 20 years old. The distribution is reasonable.

\subsection{Research technique}

We take the artificial test method from 2001 to 2002; We take the standard test according to the unification deployed which is made by physique monitor center in Shandong province among 2003 to 2008, In this study, physical tests, body shape (height, weight, chest circumference), physical function (vital capacity, step test), physical (standing long jump, Sit and Reach, 50 meters, 800 meters women, men and 1,000 meters), etc. 9 analysis of indicators ,statistics from the SPSS8.0 package to complete.

\section{Results and Analysis}

\subsection{The evaluation of physical health standards of the students of grade 2006 in QUST}

The students of 26 different classes of grade 2006 in QUST of height, weight, vital capacity, step index, Sit and Reach, standing long jump, 50 meters, 800 meters women, men and 1,000 meters, index statistical comparison can be seen, each class The average score is the highest class of 77 Chemical 062 points, bio 063 class minimum 55 points. Most of the class average scores over 70 points, only bio 061 class average score of 70 points or less, see Table 1

\section{Insert Table 1 Here}




\subsection{Body shape, physical function, physical fitness, and exercise capacity characteristics of undergraduate student of QUST}

After the index test statistics of 1969 students' height, weight, vital capacity, step index, Sit and Reach, standing long jump, 50 meters, 800 meters of women, 1,000 meters of men, and then, compared with the corresponding index of national college students. The results showed that, undergraduates' body shape indexes were higher than the national college students', the results reached the significant difference after the tests, but the vital capacity index were lower than the national college students', step index, sit and reach index were higher than the national college students', and all three physical index of standing long jump, 50 meters, 800 meters of women, and 1,000 meters of men were lower than the national college students'. After the analysis and compared the students' fitness and exercise capacity of QUST with the national college students', the results showed that, the students' jumping, endurance and lung capacity index were lower than the national students' body shape, body functions are higher than the national college students'. See Table 2.

\section{Insert Table 2 Here}

\subsection{Health standard of grade 1-4 students of QUST:}

By the test and statistical analysis of grade 1-4 students' height, weight, vital capacity, step index, Sit and Reach, standing long jump, 50 meters, 800 meters of women, 1,000 meters of men,, and then compared with the results of physical standards of national college students, we found that the proportion of fine-level of 2006 increased, proportion of qualified-level increased, proportion of unqualified-level dropped. Most of students' fitness index increased between the four yeas, but many 3-4 grade students' fitness index dropped. See Table3

\section{Insert Table 3 Here}

\section{Analysis and Discussion}

\subsection{The analysis of the overall fitness development level of students of QUST}

By the survey and test of physical development, physical function, physical fitness and exercise capacity of students of QUST, the results showed that compared with the past, the index of the students' height, weight, speed, flexibility and other indicators increased, the lack of vital capacity decreased, associated with endurance running performance has declined. This is because:(1)Junior high school to meet the "entrance" physical activity is the main reason why the main reason's constitution decline year by year;(2)Today, there are some college students having health "myths". Many of them think that they were young; it would not be the problem if they don't exercise, so they are lack of self-motivation of independent exercise other than physical education. Freshman think that they just experienced the college entrance examination and the military training, so that they need to take a break; the students of grade 3 or 4 face job select or internship outside, can not ensure the appropriate sports. As can choose their favorite sport in PE of grade2, the physical endurance increased, and the number of extracurricular physical exercises also increased. Boys weekly exercise time from 1 hour to 12 hours, mostly in 3-5 hours, the number of the girls who adhere to exercise is less, only a handful can persist 2-3 hours of weekly exercise, Most of the girls said that apart from physical education, they do no exercise. From the outcome, the students who persists exercise were more satisfied with their physical fitness. In sports, jogging and so on relatively dry, extremely useful for simple projects are easily overlooked. Most students can not fully understanding the connotation of health, there is "blind spots" in the physical training .If they think that not sick means a good body, it will make a misunderstanding in healthy outlook, all this need a proper guidance. So to accomplish sports practice by the task blindly, do not know what they need, what the need to do, is bound to duplication of efforts, ultimately difficult to develop the habit of lifelong exercise. Most of the girls and some poor physical fitness boys are reluctant in sports; do not want a long-standing physical education. The traditional Chinese sports teaching emphasis on sports technology but neglects the physical fitness for many years, in physical education, they teach skill and technology much, and most girls do not have the condition to be an athlete, so they fed on the produce physical resistance. As the students very need to beauty, they achieve the common objective of slim figure by dieting, generally timid and shy, like quiet do not like sports, most of them physical difference, their muscle strength are weak, and they afraid to act rashly during menstrual period, do not like sports.(3)The shortage of health facilities is also one reason that affect the physical comprehensive development of students.(4)Society concerned about the physical condition of young people is not enough, the school do not have a monitoring system for university, high school and primary school.(5)The only child in one's family showed more and more pampered, lack of the quality of hard-working spirit.

\subsection{The ways and means to improve the health of Students of QUST:}

According to the quality characteristics of students of QUST, We should conscientiously implement the ministry 
of education on the "School Work" instructions; use the human, physical and financial resources in improving and enhancing the physical and mental health on college students. Through physical education activities, to improve heart and lung function of students, to improve exercise capacity, to be bold in the reform in teaching materials and methods to establish a mode of physical education which have characteristics of QUST. Through the creation of basketball, soccer, table tennis and sports dance, aerobics and other students interested sports specific courses, promote students to establish a sense of physical exercise, arouse the consciousness of positive exercise, enhance the effect of physical learning. And then, with the purpose of adding the teaching content in the long-distance endurance runs, improve their running ability, effectively enhance the student body. According to the surveys and many years of teaching experience, must teach the students the principles, methods, pay attention in sports science and exercise lessons. To make the students clear how to master the proper exercise intensity, duration, frequency, how to open his own "Sports Prescription". And often combine different sports to teach the theory and practice methods. After school, teachers should teach the students how to do the physical exercise. In the class and after class, teachers should give students different exercise prescription under the individual differences.

\section{Conclusion}

5.1 The QUST students' average index of height and weight were higher than the national college students', the average index of sit and reach and step were higher than the national college students', the average index vital capacity is in the normal range. Movement quality (50 meters, long jump and 800 meters of Women, 1000 meters of Men) were lower than the national college students'.

5.2 Strengthen the physical research and health monitoring of the QUST students, provide a scientific basis for the physical education reform, suggests that put the test results of the physical form into the testing system of sports.

5.3 While the school expanding their enrollment, sports stadiums and other facilities should be strengthened in terms of building hardware ,to ensure that students have enough time and space to participate in physical exercise. Physical education should gradually move away from competitive sports-oriented teaching model, overall improve the health status of college students, and truly implement the quality education. Increase tennis, table tennis, dance, physical fitness content appropriately, cultivate their interest in learning, Stimulate their active participation in activities and improve their exercise capacity and quality.

5.4 The physical education in colleges should take care of the development of heart and lung function; strengthen the students' hard-working and so will the quality of education and training. Actively encouraged them overcome the unfavorable factor sand cultivate the good habit of exercise consciously.

5.5 Fresh up ideas, strengthen national health awareness, develop positive physical health and aesthetics. Take effective measures to enable all the people in the school building. Strengthen the students' guidance of the theoretical knowledge in physical exercise. So that they could arrangement exercise loads reasonable and scientific, enhance self-medical supervision, also can continuously improve the effect of exercise.

\section{References}

(2003). China Sports Technology, Vol. 3.

Chang Hailin. (2001). Survey and Analysis of College Students Health. Journal of Shanghai University of Sport, Vol. 5.

Guo, Jiming, (2003). Enhanced Constitution and healthy first. Journal of physical education, Vol. 2.

Hao, Shuyuan. (2003). On the Fitness and Health. Journal of Physical Education, Vol. 2.

Jia, Xiuwen. (2002). Analysis and Investigation of Health Condition of Undergraduates in Shanxi Province. Journal of Beijing University of Physical Education, Vol. 6.

Wei, Jinlong, (2003). College Students Health Research Development Law. Journal of Xi'an Institute of Physical Education, Vol. 5. 
Table 1. Division of Physical Health Standard for Students and Assessment

\begin{tabular}{|l|c|c|c|c|c|c|c|c|c|c|c|c|c|}
\hline Class & $\begin{array}{c}C E \\
031\end{array}$ & $\begin{array}{c}C E \\
032\end{array}$ & $\begin{array}{c}C E \\
033\end{array}$ & $\begin{array}{c}P E \\
032\end{array}$ & $\begin{array}{c}B i \\
031\end{array}$ & $\begin{array}{c}B i \\
033\end{array}$ & $\begin{array}{c}\text { LCE } \\
031\end{array}$ & $\begin{array}{c}\text { LCE } \\
032\end{array}$ & $\begin{array}{c}C h \\
031\end{array}$ & $\begin{array}{c}P h \\
031\end{array}$ & $\begin{array}{c}P h \\
032\end{array}$ & $\begin{array}{c}A C \\
031\end{array}$ & $\begin{array}{c}A C \\
032\end{array}$ \\
\hline Samples & 30 & 24 & 31 & 31 & 31 & 28 & 30 & 29 & 25 & 31 & 32 & 29 & 27 \\
\hline Highest score & 91 & 92 & 87 & 91 & 86 & 73 & 84 & 86 & 85 & 84 & 83 & 83 & 82 \\
\hline Minimum points & 50 & 67 & 51 & 46 & 49 & 43 & 59 & 59 & 53 & 62 & 60 & 47 & 38 \\
\hline Average & 74 & 77 & 73 & 73 & 68 & 55 & 73 & 70 & 72 & 74 & 72 & 72 & 71 \\
\hline Standard deviation & 29 & 45 & 9 & 9 & 16 & 17 & 15 & 20 & 26 & 6 & 6 & 24 & 16 \\
\hline Class & $M C$ & $M C$ & $E E$ & $E E$ & $P E$ & $S E$ & $S E$ & $N M$ & $N M$ & $P M$ & $P M$ & $P E$ & $B i$ \\
& 031 & 032 & 031 & 032 & 032 & 031 & 032 & 031 & 032 & 033 & 034 & 034 & 034 \\
\hline Samples & 25 & 27 & 30 & 30 & 18 & 27 & 26 & 32 & 30 & 23 & 25 & 25 & 37 \\
\hline Highest score & 87 & 92 & 92 & 86 & 86 & 91 & 97 & 87 & 88 & 92 & 83 & 84 & 85 \\
\hline Minimum points & 53 & 52 & 12 & 41 & 41 & 57 & 50 & 43 & 58 & 56 & 55 & 58 & 24 \\
\hline Average & 72 & 74 & 72 & 71 & 71 & 72 & 71 & 73 & 73 & 71 & 73 & 72 & 71 \\
\hline Standard deviation & 26 & 8 & 14 & 9 & 9 & 25 & 22 & 8 & 7 & 8 & 7 & 15 & 10 \\
\hline
\end{tabular}

Table 2. Compare the compliance value of the overall sample of undergraduate students of QUST (men and women)with compliance value of the overall sample of the national college students(men and women)

\begin{tabular}{|l|l|l|l|l|l|l|l|l|}
\hline & Height & Weight & $\begin{array}{l}\text { Vital } \\
\text { Capacity }\end{array}$ & $\begin{array}{l}\text { Step } \\
\text { Index }\end{array}$ & $\begin{array}{l}\text { Sit and } \\
\text { Reach }\end{array}$ & $\begin{array}{l}\text { Standing } \\
\text { Long } \\
\text { Jump }\end{array}$ & $\begin{array}{l}\text { 50M } \\
\text { W00M } \\
\text { Women,1000M } \\
\text { of Men }\end{array}$ \\
\hline Men.QUST & 173.6 & 63.228 & 3585.6 & 51.536 & 12.9816 & 221.504 & 8.126 & 228.321 \\
\hline Men .National & 170.008 & 59.887 & 3637.915 & 51.270 & 12.797 & 250.206 & 8.371 & 226.852 \\
\hline Women .QUST & 162.4184 & 61.364 & 2309.843 & 50.888 & 15.4184 & 157.792 & 6.514 & 223.713 \\
\hline Women .National & 157.739 & 50.848 & 2506.587 & 50.859 & 12.194 & 191.316 & 6.919 & 218.152 \\
\hline
\end{tabular}

Table 3. Compared the students' fitness index of QUST with the students' fitness index of the national college students

\begin{tabular}{|c|c|c|c|c|c|c|c|c|c|}
\hline grade & Samples & $\begin{array}{c}\text { Outstanding } \\
\text { number }\end{array}$ & $\begin{array}{c}\text { Excellent } \\
\text { rates }\end{array}$ & $\begin{array}{c}\text { Good } \\
\text { number }\end{array}$ & $\begin{array}{c}\text { Good } \\
\text { rate }\end{array}$ & $\begin{array}{c}\text { Passing } \\
\text { number }\end{array}$ & $\begin{array}{c}\text { Passing } \\
\text { rate }\end{array}$ & $\begin{array}{c}\text { Failure } \\
\text { number }\end{array}$ & $\begin{array}{c}\text { Failure } \\
\text { rate }\end{array}$ \\
\hline Freshman & 733 & 95 & $13 \%$ & 257 & $35 \%$ & 330 & $45 \%$ & 51 & $7 \%$ \\
\hline Sophomore & 736 & 59 & $8 \%$ & 243 & $33 \%$ & 375 & $51 \%$ & 59 & $8 \%$ \\
\hline Junior & 250 & 11 & $5 \%$ & 76 & $30 \%$ & 138 & $55 \%$ & 25 & $10 \%$ \\
\hline Senior & 250 & 9 & $4 \%$ & 70 & $28 \%$ & 143 & $57 \%$ & 28 & $11 \%$ \\
\hline $\begin{array}{c}\text { National } \\
\text { University }\end{array}$ & 1050328 & 126039 & $12 \%$ & 273085 & $25.90 \%$ & 350810 & $33.40 \%$ & 300384 & $28.60 \%$ \\
\hline
\end{tabular}

